\title{
Partial Resistance Stability of Some Common Potato Cultivars to Natural Late Blight Infection Caused by Phytophthora infestans under Egyptian Conditions
}

\author{
Essa, T.A.; Kamel, S.M.; Ismail, A.M. and Omara, \\ R.I. \\ Plant Pathology Research Institute, Agricultural Research \\ Centre, Giza, Egypt
}

Tate blight caused by Phytophthora infestans is one of the most $\mathbf{U}_{\text {devastating diseases on potato worldwide. Partial resistance (PR) }}$ to the oomycete pathogen Phytophthora infestans was studied for ten potato cultivars in Beheira, Gharbia and Kafr El-Sheikh governorates in Egypt. Final disease severity (FDS\%), area under disease progress curve (AUDPC) and rate of disease increase (r-value) were used as epiphytotic parameters to estimate PR during the growing seasons of 2016 and 2017. The cvs. Burren, Cara and Bellini exhibited the highest levels of PR to late blight, where they showed lowest values of FDS (\%), AUDPC and r-value in both seasons of evaluation. Four measures i.e., means $\overline{\mathrm{x}}$, regression coefficient $\left(\mathrm{b}_{1}\right)$, standard deviation $\left(S^{2} d\right)$ and ecovalance (wi) were used for determining the partial stability resistance of the tested potato cvs., to late blight infection. Stability parameters clearly showed that cv. Bellini was the most stable to late blight under wide range of environmental conditions. The stability analysis can help breeders to monitor the level of resistance of the tested plant material as well as to monitor the disease pressure in different environments.

Keywords: Phytophthora infestans, potato, partial resistance, stability parameters.

Potato (Solanum tuberosum L.) is the third important food crop in the world after rice and wheat (Haverkortet al., 2009). In 2017 season, Egypt exported 6.6\% of entire exported potato quantities of 15 countries with cash income reached US\$ 272.7 million (Workman 2018). Potato late blight caused by Phytophthora infestans (Mont.) de Bary, is one of the most important diseases to potato worldwide (Andrivon, 1995). The annual costs for controlling potato late blight were estimated to be $6.7 \$$ billion worldwide (Haverkort et al., 2008). Management of such disease requires integrated measures including, cultural, scouting, sanitation in addition to combination of host plant resistance with application of fungicides (Johnson et al., 1998 and Kirk et al., 2005). The main obstacle in the control of late blight is the short duration and rapid loss of host-genetic resistance, due to the breaking down or a rapidly overcome of newly deployed resistance genes as a result of the evolution 
or emergence of new virulent races in pathogen populations (Sparks et al., 2014). Potato cultivars that able to slowdown the developments of late blight during an epidemic in the field are considered to have partial resistance (PR) (Parlevli et al., 1979). PR can be identified by specific components that limit the infection process. These components that have been identified in Solanum germplasm include lower infection efficiency, slower lesion growth rate, longer generation time or latent period, shorter infectious period, and/or slower sporulation rate (Colon and Budding, 1988; Rivera-Peña, 1990; Tooley, 1990; Colon et al., 1995).

The current study aimed to evaluate stability of PR of potato cultivars to late blight under the wide range of environmental conditions in Egypt to distinguish potato cultivars with highest PR stability.

\section{Materials and Methods}

\section{Source of potato tubers as seeds.}

Tubers of the following ten potato cultivars; Agria, Bellini, Burren, Cara, Diamont, Herms, Lady Rosetta, Nicola, Picasso and Spunta were obtained from the Potato Brown Rot Project, Giza, Egypt, to study their responses to late blight under natural infection. Apparently healthy tuber seeds were planted during December 2016 and December 2017 in three locations; Beheira, Gharbia and Kafr El-Sheikh.

\section{Prevalent races of $P$. infestans under investigated fields.}

The prevalent races under investigation areas (Beheira, Gharbia and Kafr ElSheikh governorates) were identified as 23_A1_10, 23_A1_12, 23_A1_21, 23_A1_25, 23_A1_31,23_A1_34 and 23_A1_35 during seasons 2012/2013, where, clonal lineage 23_A1 was the predominant through the last five years into Egyptian populations and all isolates belonging to A1 mating type and mtDNA (Arafa et. al., 2017)

\section{Experimental design.}

The experiment was designed as randomized complete block design (RCBD) with three plots as a replicate per each cultivar. Each plot $(6 \times 7 \mathrm{~m})$ comprised of 8 rows $0.75 \mathrm{~m}$ width and $0.30 \mathrm{~m}$ distance between cultivated tubers.

\section{Assessment of epiphytotic parameters}

Disease severity (DS) \% was recorded according to Chen et al. (2014) using the visual scale (0-6).

Potato late blight disease severity was recorded at 45 days of planting for four times with 7days' interval between readings during the two growing seasons of 2016 and 2017. The obtained data served in the determination of final disease severity\% (FDS), area under disease progress curve (AUDPC) and rate of disease increase ( $r$ value). 
Table 1: Key of disease assessment.

\begin{tabular}{|c|c|c|}
\hline $\begin{array}{c}\text { Scale } \\
\text { categories }\end{array}$ & Symptoms characterization & Reaction degree \\
\hline 0 & No symptoms & Immune \\
\hline 1 & $5 \%$ of leaf area affected and small lesions & Highly resistant \\
\hline 2 & $\begin{array}{l}\text { More than } 5 \% \text { to } 15 \% \text { of leaf area affected and } \\
\text { restricted lesions }\end{array}$ & Resistant \\
\hline 3 & $\begin{array}{l}\text { More than } 15 \% \text { to } 30 \% \text { of leaf area affected } \\
\text { and/or water-soaked flecks on stems }\end{array}$ & $\begin{array}{l}\text { Moderately } \\
\text { susceptible }\end{array}$ \\
\hline 4 & $\begin{array}{l}\text { More than } 30 \text { to } 60 \% \text { of leaf area affected } \\
\text { and/or a few stem lesions }\end{array}$ & $\begin{array}{l}\text { Moderately } \\
\text { susceptible }\end{array}$ \\
\hline 5 & $\begin{array}{l}\text { More than } 60 \% \text { to } 90 \% \text { of leaf area affected } \\
\text { and expanding stem lesions }\end{array}$ & Susceptible \\
\hline 6 & $\begin{array}{l}\text { More than } 90 \% \text { to } 100 \% \text { of leaf area affected, } \\
\text { extensive stem damage, or a dead plant }\end{array}$ & $\begin{array}{c}\text { Highly } \\
\text { susceptible }\end{array}$ \\
\hline
\end{tabular}

Whereas, area under disease progress curve (AUDPC) was estimated to compare different responses of the tested cultivars, the following equation described by Pandey et al. (1989):

Where:

$$
\mathrm{AUDPC}=\mathrm{D}\left[1 / 2\left(\mathrm{Y}_{1}+\mathrm{Y}_{\mathrm{K}}\right)+\mathrm{Y}_{2}+\mathrm{Y}_{3}+\ldots+\mathrm{Y}_{(\mathrm{K}-1)}\right]
$$

\footnotetext{
$\mathrm{D}=$ Days between readings.

$\mathrm{Y}_{1}=$ First disease record

$\mathrm{Y}_{\mathrm{k}}=$ last disease record.
}

On the other hand, r-value, was also estimated as a function of time to determine the ability of each cultivar under the current study to delay or slowdown the development or increase of infection under field conditions. It was calculated from the different scores as a severity of infection at the first time of appearance and each 7 days intervals. R-value was estimated according to Van der Plank (1963) using the following equation:

Where:

$$
R \text {-value }=1 / t_{2}-t_{1}\left(\log _{e} X_{2} / 1-X_{2}-\log _{e} X_{2} / 1-X_{1}\right)
$$

$\mathrm{X}_{1}=$ Disease severity $(\%)$ at $\mathrm{t}_{1}$ date.

$\mathrm{X}_{2}=$ Disease severity $(\%)$ at $\mathrm{t}_{2}$ date.

$\mathrm{t}_{2}-\mathrm{t}_{1}=$ Time interval in days between two observations.

5. Stability analysis:

The statistical analysis for stability was carried out according to the method described by Eberhart and Russell (1966). This method considers the coefficients of linear regression of the disease values from each genotype concerning the 
environmental index and the deviations of this regression to select genotypes with stability and adaptability to favorable and unfavorable environments of partial resistance to late blight in the tested potato cvs.

The parameters of regression coefficient (bi) and mean squares of deviation from regression $\left(S^{2} d\right)$ for each genotype were estimated. Pooled error in the regression analysis of variance was used to test whether deviation mean square was significantly different from zero. Hence, the definition of the stable genotype will be the one with low mean, $b=1$ and $S^{2} d=0$.

5.a. The regression coefficient (bi) which is the regression of the performance of each genotype under different environments on the environmental mean over all genotypes, is estimated using the following equations:

$$
\begin{aligned}
& \mathrm{b}_{\mathrm{i}}=\sum_{\mathrm{j}} \mathrm{y}_{\mathrm{ij}} \mathrm{I}_{\mathrm{j}} / \sum_{\mathrm{j}} \mathrm{I}_{\mathrm{j}}^{\mathrm{I}} \\
& \mathrm{Ij}=\left(\sum_{\mathrm{i}} \mathrm{y}_{\mathrm{ij}} /{ }_{\mathrm{v}}\right)-\left(\sum_{\mathrm{i}} \sum_{\mathrm{j}} \mathrm{y}_{\mathrm{ij}} / \mathrm{vn}\right), \sum_{\mathrm{j}} \mathrm{I}=0 .
\end{aligned}
$$

Where:

$$
\begin{aligned}
& B i=\text { Regression coefficient. } \\
& I_{j}=\text { The environmental index. } \\
& y_{i j}=\text { A mean performance of character on } i^{\text {th }} \text { cultivar in } j^{\text {th }} \text { environment } j . \\
& v=\text { Number of cultivars. } \\
& n=\text { Number of environments. }
\end{aligned}
$$

5.b. The deviations from regression $\left(\mathrm{S}^{2} \mathrm{~d}\right)$ can be summarized to provide an estimate of another stability parameter.

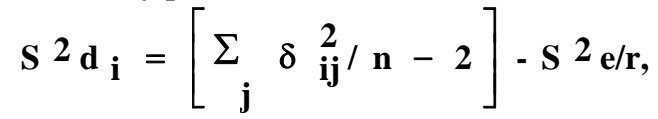

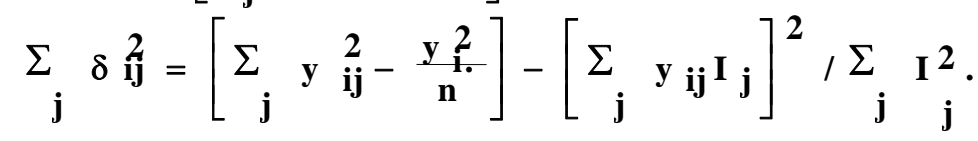

Where:

$S^{2} d_{i}=$ Deviations from regression of each cultivar.

$\mathrm{S}^{2} \mathrm{e} / \mathrm{r}=$ The estimate of pooled error.

$\mathrm{Yi}=$ Total of the $\mathrm{i}^{\text {th }}$ cultivar of all environments.

5.c. The second measurement was the ecovalence (wi); the contribution of each cultivar to the genotype $\mathrm{x}$ environment interaction. It was calculated for each cultivar according to the equation of Wricke (1962):

Where:

$$
\mathrm{W}_{\mathrm{i}}=\sum_{\mathrm{j}}\left(\overline{\mathrm{x}}_{\mathrm{ij}}-\mathrm{x}_{\mathrm{j}}^{-}\right)^{2}-\left(\overline{\mathrm{x}}_{\mathrm{j} \cdot} \cdot \mathrm{x}^{-}\right)^{2}
$$

Egypt. J. Phytopathol., Vol. 46, No. 2 (2018) 
$\overline{\mathrm{x}}_{\mathrm{ij}}=\mathrm{a}$ mean performance of character on the $\mathrm{i}^{\text {th }}$ cultivar in $\mathrm{j}^{\text {th }}$ environment,

$\bar{x}_{. j}=$ mean of the $j^{\text {th }}$ environment of all cultivars.

$\mathrm{x}_{\mathrm{i}} .=$ mean of the $\mathrm{i}^{\text {th }}$ cultivar of all environments.

$\mathrm{x}=$ grand mean.

\section{Statistical analysis:}

Analysis of variance of separate environments was carried out for each trait. A combined analysis of variance was computed overall the environments. Separate estimates of the components of variation were calculated to evaluate the magnitude of the different effects according to Sendecor and Cochran (1969). Least significant difference test (LSD) was used to detect differences between genotypes over all the studied environments.

\section{Results}

1. Partial resistance of potato cultivars to late blight under field conditions:

Partial resistance to late blight was characterized for each cultivar by estimating the three epiphytotic parameters; FDS (\%), AUDPC and r-value under field conditions in three locations during 2016 and 2017.

\subsection{Final disease severity (FDS \%):}

Potato cultivars, i.e. Agria, Lady Rosetta, Diamont, Spunta, Herms, Nicola and Picasso were the most susceptible ones to late blight infection among the other tested cultivars during 2016 and 2017 (Table 2). In this respect, the highest FDS \% was $69.4 \%$ with the highly susceptible cv. Diamont cultivated in Kafr El-Sheikh governorate followed by $66.9 \%$ with cv. Lady Rosetta cultivated in Beheira governorate during season 2016. While, in the second season $2017 \mathrm{cvs}$. Diamont and Lady Rosetta which cultivated in Kafr El-Sheikh were the highest susceptible ones where they recorded FDS\% 81.9 and $80.2 \%$, respectively (Table 2). Where, the least FDS\% were recorded with the three potato cultivars, i.e., Burren, Cara and Bellini to be the more resistant ones to late blight infection among the other tested potato cvs. In Beheira, Kafr El-Sheikh and Gharbia governorates during seasons 2016 and 2017.

\subsection{Area under disease progress curve (AUDPC):}

AUDPC Data of the three locations during two growing seasons 2016 and 2017 divided the tested potato cultivars into two main groups. The first group included potato cultivars with the lowest values of AUDPC (less than 450), i.e. Burren (308.35, 415.80 and 419.65), Cara (217.7, 291.55 and 323.4) and Bellini (351.75, 340.20 and 244.30), at the three locations, respectively, in 2016. Meanwhile, in 2017, AUDPC values were (436.65, 462.80 and 393.4), (305.55, 425.60 and411.50) and $(416.15,449.50$ and 421.75$)$, for the above-mentioned three cultivars at the three locations, respectively.

In contrast, the second group included potato cultivars with high values of AUDPC, included the highly susceptible potato cultivars, i.e. Agria, Lady Rosetta, Diamont, Spunta and Herms, these cultivars revealed, in general, the highest levels of late blight infection under field conditions, during the two growing seasons of the 
three tested locations (Table, 3 and Fig 1). Therefore, this group of cultivars could be classified as highly susceptible.

Table 2: Percentage of final disease severity (FDS) of late blight on 10 potato cultivars cultivated in Beheira, Kafr El-Sheikh and Gharbia governorates during seasons 2016 and 2017

\begin{tabular}{|l|c|c|c|c|c|c|}
\hline \multirow{3}{*}{\begin{tabular}{c}
\multirow{2}{*}{$\begin{array}{c}\text { Potato } \\
\text { cultivars }\end{array}$} \\
\cline { 2 - 7 }
\end{tabular}} & \multicolumn{5}{|c|}{ Season 2016 } & \multicolumn{3}{c|}{ Season 2017 } \\
\cline { 2 - 7 } & Beheira & $\begin{array}{c}\text { Kafr } \\
\text { El-heikh }\end{array}$ & Gharbia & Beheira & $\begin{array}{c}\text { Kafr } \\
\text { El-heikh }\end{array}$ & Gharbia \\
\hline Agria & 60.2 & 63.4 & 58.8 & 64.6 & 79.4 & 64.2 \\
\hline Picasso & 46.6 & 47.8 & 40.9 & 44.6 & 64.1 & 60.8 \\
\hline Lady Rosetta & 66.9 & 65.2 & 62.2 & 78.8 & 80.2 & 74.7 \\
\hline Diamont & 62.4 & 69.4 & 66.4 & 65.5 & 81.9 & 69.2 \\
\hline Burren & 28.2 & 31.7 & 33.9 & 38.2 & 41.4 & 34.5 \\
\hline Herms & 51.9 & 53.1 & 50.3 & 66.2 & 71.5 & 58.0 \\
\hline Spunta & 61.2 & 65.2 & 55.7 & 67.2 & 74.5 & 63.3 \\
\hline Cara & 19.3 & 24.8 & 24.6 & 22.6 & 36.7 & 39.2 \\
\hline Bellini & 28.3 & 29.4 & 26.2 & 36.6 & 40.3 & 36.1 \\
\hline Nicola & 48.7 & 49.3 & 42.9 & 58.3 & 68.8 & 62.4 \\
\hline L.S.D* ${ }_{0.05}$ & \multicolumn{7}{|c|}{3.59} & \\
\hline
\end{tabular}

L.S.D* ${ }_{0.05}$ for: interaction (season $\times$ location $\times$ cultivar).

Table 3: Area under disease progress curve (AUDPC) of late blight on 10 potato cultivars cultivated in Beheira, Kafr El-Sheikh and Gharbia governorates during seasons 2016 and 2017

\begin{tabular}{|c|c|c|c|c|c|c|}
\hline \multirow{3}{*}{$\begin{array}{c}\text { Potato } \\
\text { cultivars }\end{array}$} & \multicolumn{6}{|c|}{ Area under disease progress curve (AUDPC) } \\
\hline & \multicolumn{3}{|c|}{ Season 2016} & \multicolumn{3}{|c|}{ Season 2017} \\
\hline & Beheira & $\begin{array}{l}\text { Kafr El- } \\
\text { Sheikh }\end{array}$ & Gharbia & Beheira & $\begin{array}{l}\text { Kafr El- } \\
\text { Sheikh }\end{array}$ & Gharbia \\
\hline Agria & 759.85 & 830.55 & 714.70 & 907.20 & 1135.40 & 907.55 \\
\hline Picasso & 669.10 & 679.00 & 667.35 & 646.80 & 865.55 & 786.10 \\
\hline Lady Rosetta & 859.60 & 935.55 & 779.45 & 1009.40 & 1113.70 & 1025.15 \\
\hline Diamont & 794.85 & 980.35 & 810.25 & 926.80 & 1211.70 & 929.95 \\
\hline Burren & 308.35 & 415.80 & 419.65 & 436.65 & 462.80 & 393.40 \\
\hline Herms & 648.9 & 679.35 & 618.25 & 827.75 & 1058.75 & 672.00 \\
\hline Spunta & 758.45 & 832.30 & 709.45 & 849.80 & 988.75 & 911.40 \\
\hline Cara & 217.70 & 291.55 & 323.40 & 305.55 & 425.60 & 411.50 \\
\hline Bellini & 351.75 & 340.20 & 244.30 & 416.15 & 449.50 & 421.75 \\
\hline Nicola & 600.25 & 615.30 & 514.15 & 801.50 & 921.55 & 820.05 \\
\hline L.S.D* ${ }_{0.05}$ & \multicolumn{6}{|c|}{16.34} \\
\hline
\end{tabular}

L.S.D* ${ }^{*} 0.05$ for: interaction (season $\times$ location $\times$ cultivar).

Egypt. J. Phytopathol., Vol. 46, No. 2 (2018) 


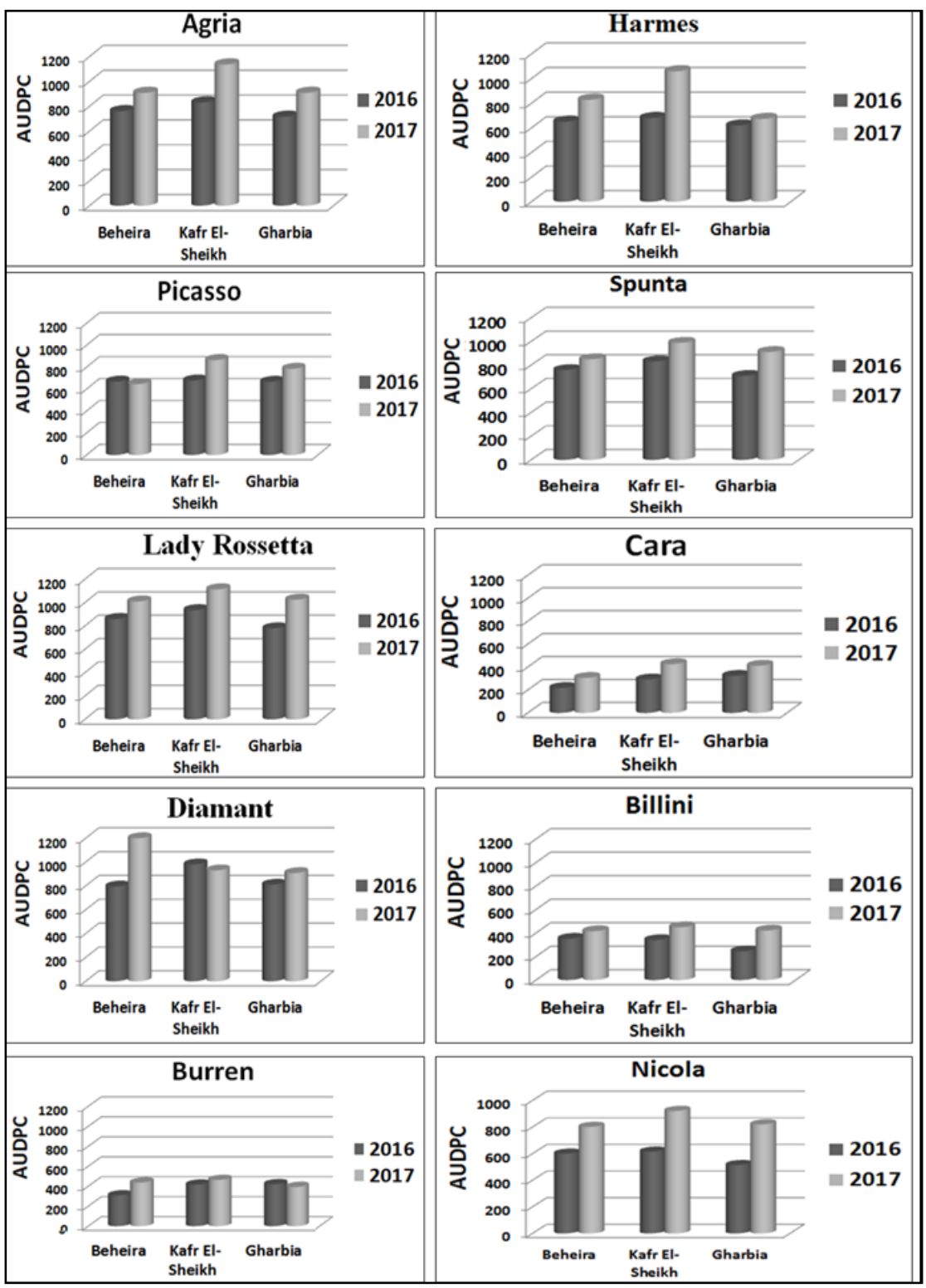

Fig.1: Area under disease progress curve (AUDPC) of late blight on 10 potato cultivars cultivated in three locations during 2016 and 2017 growing seasons. 


\subsection{Rate of disease increase ( $r$-value):}

Out of ten potato cultivars, only three cultivars recorded the lowest r-values (less than 0.099), i.e. Burren, Cara and Bellini, in the three locations, during 2016 and 2017 growing seasons. So, they were classified as the partly resistant group of cultivars, in comparison with the highly susceptible cultivars; Lady Rosetta and Diamont (Table, 4).

\section{Combined analysis of variance for three epiphytotic parameters:}

Combined analysis of variance was carried out over the three locations, during seasons 2016 and 2017. Significant differences were recorded among growing seasons (S), locations (L), tested cultivars (C), and the interaction among them, in terms of FDS (\%) and AUDPC in 2016 and 2017 seasons (Table, 5). However, there was no significant difference among locations (L) and the interaction among growing seasons (S), locations (L) and the tested cultivars (C) in terms of $r$ - value (Table, 5). Due to the significance of the interaction among growing seasons, locations and cultivars ( $\mathrm{S} \times \mathrm{L} \times \mathrm{C}$ ), L.S.D. values were used to compare the differences in FDS (\%) and AUDPC means of any two cultivars within each environment (growing season or locations).

Table 4: Rate of increase (r-value) of late blight development on potato cultivars grown in Beheira, Kafr El-Sheikh and Gharbia during 2016 and 2017growing seasons

\begin{tabular}{|l|c|c|c|c|c|c|c|}
\hline \multirow{2}{*}{$\begin{array}{c}\text { Potato } \\
\text { cultivars }\end{array}$} & \multicolumn{5}{|c|}{ Area under disease progress curve (AUDPC) } & \multirow{3}{*}{ Mean } \\
\cline { 2 - 8 } & Beheira & $\begin{array}{c}\text { Kafr El- } \\
\text { Sheikh }\end{array}$ & Gharbia & Beheira & $\begin{array}{c}\text { Kafr El- } \\
\text { Sheikh }\end{array}$ & Gharbia & \\
\hline Agria & 0.126 & 0.131 & 0.106 & 0.137 & 0.157 & 0.140 & 0.133 \\
\hline Picasso & 0.103 & 0.108 & 0.100 & 0.099 & 0.134 & 0.121 & 0.111 \\
\hline Lady Rosetta & 0.131 & 0.141 & 0.121 & 0.147 & 0.150 & 0.151 & 0.140 \\
\hline Diamont & 0.121 & 0.144 & 0.131 & 0.138 & 0.165 & 0.139 & 0.140 \\
\hline Burren & 0.064 & 0.080 & 0.083 & 0.098 & 0.099 & 0.078 & 0.084 \\
\hline Herms & 0.101 & 0.119 & 0.100 & 0.130 & 0.149 & 0.106 & 0.118 \\
\hline Spunta & 0.120 & 0.135 & 0.129 & 0.133 & 0.142 & 0.136 & 0.133 \\
\hline Cara & 0.050 & 0.069 & 0.096 & 0.090 & 0.083 & 0.093 & 0.080 \\
\hline Bellini & 0.079 & 0.069 & 0.067 & 0.097 & 0.099 & 0.083 & 0.082 \\
\hline Nicola & 0.099 & 0.117 & 0.093 & 0.111 & 0.132 & 0.114 & 0.111 \\
\hline Mean & 0.099 & 0.111 & 0.103 & 0.118 & 0.131 & 0.116 & - \\
\hline L.S.D. 0.05 & for: Cultivars (C) $=0.003$, Season $(\mathrm{S})=0.022$, Locations (L) $=\mathrm{ns,}$ \\
\hline
\end{tabular}

Egypt. J. Phytopathol., Vol. 46, No. 2 (2018) 
Table 5: Combined analysis of variance of three locations and two growing seasons for $\operatorname{FDS}^{\mathrm{a}}(\%), \operatorname{AUDPC}^{\mathrm{b}}$ and r-value ${ }^{\mathrm{c}}$ for potato cultivars

\begin{tabular}{|c|c|c|c|c|}
\hline \multirow{2}{*}{ Source of var. } & \multirow{2}{*}{ DF } & \multicolumn{3}{|c|}{ Mean square } \\
\cline { 3 - 5 } & & FDS $^{\mathrm{a}}(\%)$ & AUDPC $^{\mathrm{b}}$ & r-value $^{\mathrm{c}}$ \\
\hline Growing seasons (S) & 1 & $5431.258^{*}$ & $1488969.67^{*}$ & $0.056^{* *}$ \\
\hline Locations (L) & 2 & $708.339^{*}$ & $283505.926^{*}$ & $0.008^{\mathrm{ns}}$ \\
\hline $\mathrm{S} \times \mathrm{L}$ & 2 & $161.400^{*}$ & $24542.576^{*}$ & $0.037^{* *}$ \\
\hline $\mathrm{R}(\mathrm{LS})$ & 12 & 69.415 & 406.050 & 0.005 \\
\hline Cultivars $(\mathrm{C})$ & 9 & $4394.684^{*}$ & $920891.903^{*}$ & $0.010^{*}$ \\
\hline $\mathrm{S} \times \mathrm{C}$ & 9 & $40.113^{*}$ & $10750.568^{*}$ & $0.008^{\mathrm{ns}}$ \\
\hline $\mathrm{L} \times \mathrm{C}$ & 18 & $62.869^{*}$ & $18287.636^{*}$ & $0.006^{\mathrm{ns}}$ \\
\hline S $\times \mathrm{L} \times \mathrm{C}$ & 18 & $53.331^{*}$ & $10265.179^{*}$ & $0.004^{\mathrm{ns}}$ \\
\hline Error & 108 & 4.930 & 101.698 & 0.006 \\
\hline
\end{tabular}

$\operatorname{FDS}^{\mathrm{a}}(\%)=$ final disease severity, $\mathrm{AUDPC}^{\mathrm{b}}=$ area under disease progress curve and r-value ${ }^{c}=$ rate of disease increase. $*=$ Significant at $0.05 * *=$ highly significant at $0.01 \mathrm{~ns}=$ insignificant.

3. Effect of growing seasons, locations and genotypes as well as their interaction on the variation of the two epiphytical parameters, FDS (\%) and AUDPC:

Relative contribution, expressed as the percentage of mean square of the explained model variation, was estimated for each parameter under study, i.e. FDS (\%) and AUDPC (Table, 6 and Fig. 2).

The genetic structure of the tested cultivars had a relative contribution of $78.26 \%$ and $75.21 \%$ on the variation found in FDS (\%) and AUDPC, respectively (Table 6). On the other hand, the relative contribution of environments (season and locations) was much lower (less than $2 \%$ ).

Table 6: Relative contribution of $S, L$ and $V$ and their interactions on the variation of the two epiphytotic parameters to $P R$ against potato late blight

\begin{tabular}{|c|c|c|}
\hline \multirow{2}{*}{ Variable } & \multicolumn{2}{|c|}{ Relative contribution $(\%)$} \\
\cline { 2 - 3 } & FDS $^{\mathrm{a}}(\%)$ & AUDPC $^{\mathrm{b}}$ \\
\hline Growing seasons(S) & 10.75 & 13.51 \\
\hline Locations (L) & 2.80 & 5.15 \\
\hline Cultivars (V) & 78.26 & 75.21 \\
\hline Interaction $(\mathrm{S} \times \mathrm{L} \times \mathrm{V})$ & 1.89 & 1.68 \\
\hline
\end{tabular}

$\operatorname{FDS}^{\mathrm{a}}(\%)=$ final disease severity and $\mathrm{AUDPC}^{\mathrm{b}}=$ area under disease progress curve. 


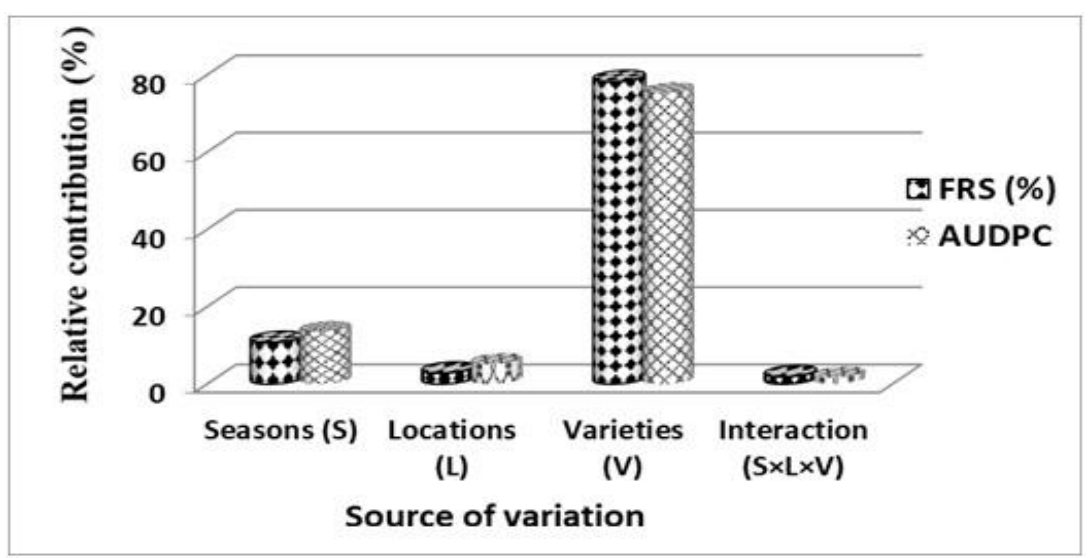

Fig. 2: Relative contribution of $S, L$ and $V$ and their interaction on the variation of FDS \% and AUDPC.

4. Estimates of stability parameters for the two epiphytic parameters, FDS (\%) and AUDPC over different environments:

The obtained (bi) values in Tables ( 7 and 8 ) did not significantly deviate from the unity for all the tested genotypes and in the two of the epiphytic parameters, i.e. FDS $\%$ and AUDPC. On the other hand, the interaction between genotype and environment of $r$-value was not-significant resulting in inability to conduct the stability analysis of this epiphytic parameters (FDS \% and AUDPC).

Table 7: Stability parameters of PR to late blight expressed as FDS (\%) on potato cultivars

\begin{tabular}{|l|c|c|c|c|}
\hline \multirow{2}{*}{$\begin{array}{c}\text { Potato } \\
\text { cultivars }\end{array}$} & $\overline{4}$ Stability parameters \\
\cline { 2 - 5 } & $\overline{\mathrm{x}}$ & Ecovalence & $\begin{array}{c}\text { Standard } \\
\text { deviation }\end{array}$ & $\begin{array}{c}\text { Regression } \\
\text { coefficient }\left(\mathrm{b}_{\mathrm{i}}\right)\end{array}$ \\
\hline Agria & 71.33 & 36.710 & $5.473^{\text {ns }}$ & $0.998^{\text {ns }}$ \\
\hline Picasso & 69.13 & 129.072 & $27.040^{*}$ & $1.158^{\text {ns }}$ \\
\hline Lady Rosetta & 65.10 & 49.527 & $8.641^{*}$ & $1.001^{\text {ns }}$ \\
\hline Diamont & 64.52 & 76.489 & $13.540^{*}$ & $0.823^{\text {ns }}$ \\
\hline Burren & 58.50 & 178.003 & $35.815^{*}$ & $0.710^{\text {ns }}$ \\
\hline Herms & 55.07 & 55.142 & $8.458^{*}$ & $1.164^{\text {ns }}$ \\
\hline Spunta & 50.80 & 47.347 & $6.148^{\text {ns }}$ & $0.818^{\text {ns }}$ \\
\hline Cara & 36.43 & 182.692 & $41.458^{*}$ & $0.910^{\text {ns }}$ \\
\hline Bellini & 33.65 & 2.847 & $3.079^{\text {ns }}$ & $1.029^{\text {ns }}$ \\
\hline Nicola & 28.20 & 57.082 & $1.794^{\text {ns }}$ & $1.384^{\text {ns }}$ \\
\hline
\end{tabular}

ns $=$ Insignificant and $*=$ Significant at 0.05

Egypt. J. Phytopathol., Vol. 46, No. 2 (2018) 
Table 8: Stability parameters of PR to late blight expressed as AUDPC (\%) on potato cultivars

\begin{tabular}{|l|c|c|c|c|}
\hline \multirow{2}{*}{$\begin{array}{c}\text { Potato } \\
\text { cultivars }\end{array}$} & $\overline{\mathrm{X}}$ & Ecovalence & $\begin{array}{c}\text { Standard } \\
\text { Deviation }\end{array}$ & $\begin{array}{c}\text { Regression } \\
\text { coefficient } \\
(\mathrm{b} 1)\end{array}$ \\
\cline { 2 - 5 } & 953.81 & 5882.54 & $1991.85^{\mathrm{ns}}$ & $1.247^{\mathrm{ns}}$ \\
\hline Agria & 942.32 & 10829.70 & $242.97^{\mathrm{ns}}$ & $0.932^{\mathrm{ns}}$ \\
\hline Picasso & 875.88 & 15259.06 & $1399.01^{\mathrm{ns}}$ & $0.828^{\mathrm{ns}}$ \\
\hline Lady Rossetta & 841.69 & 18991.27 & $1830.78^{\mathrm{ns}}$ & $1.174^{\mathrm{ns}}$ \\
\hline Diamont & 730.33 & 49249.72 & $7982.36^{*}$ & $0.667^{\mathrm{ns}}$ \\
\hline Burren & 712.13 & 43303.13 & $3853.95^{\mathrm{ns}}$ & $1.511^{\mathrm{ns}}$ \\
\hline Hermes & 685.65 & 4748.27 & $1705.68^{\mathrm{ns}}$ & $0.830^{\mathrm{ns}}$ \\
\hline Spunta & 456.11 & 40605.04 & $3976.59^{\mathrm{ns}}$ & $0.535^{\mathrm{ns}}$ \\
\hline Cara & 387.28 & 3947.89 & $1353.13^{\mathrm{ns}}$ & $0.994^{\mathrm{ns}}$ \\
\hline Billini & 340.55 & 6201.26 & $64.43^{\mathrm{ns}}$ & $1.278^{\mathrm{ns}}$ \\
\hline Nicola & & & & \\
\hline
\end{tabular}

\section{D i s c u s s i on}

The present study was carried out to analyze partial resistance of ten potato cultivars to late blight grown in three locations, during two growing seasons of evaluation. The ability of the tested potato cultivars to slowdown and delay the development of late blight infection was estimated and considered as APR or PR under field conditions.

Due to the relatively slight changes in environmental factors that favor disease incidence and development from one year to another, late blight epiphytic was found to be higher in its magnitude in 2017 than 2016. On the other hand, Kafr El-Sheikh location recorded the highest level of FDS \% during the two seasons. The three potato cultivars; Burren, Cara and Bellini revealed the highest levels of PR to late blight infection indicating that the performance of these cultivars which measured by FDS \% were phenotypically stable across environmental conditions in the three locations, i.e., Beheira, Kafr El-Sheikh and Gharbia. This finding explains well the ability of the three cultivars to maintain high levels of resistance in the three locations in 2017 when the environmental conditions were more favorable to disease onset than in 2016.

According to variation of AUDPC, therefore, the three cultivars were designated or characterized as partially resistant. Similarly, Jenkins and Jones (2003) classified potato cultivars into four levels for resistance to fungus like P. infestans based on AUDPC in the United States. Furthermore, Haynes et al. (1998) found that only four 
clones; AWN86514-2, B0692-4, B0718-3 and B0767-2 out of 16 U.S.A clones exhibited PR to late blight based on their low AUDPC score. Moreover, Haynes and Weingartner (2004) relied also on the values of AUDPC for selecting the resistant potato genotypes. Therefore, it could be concluded that AUDPC was used to assess differences in late blight resistance between potato clones (Kathleen and Peter 2004). Gopal and Singh, (2003) attributed the variation in AUDPC values to the absence or presence of different minor genes for resistance to late blight in potato cultivars. Generally, disease severity developed rapidly and increased at relatively lower rates (r-values) in Kafr El-Sheikh location in 2016 and 2017. Insignificant effect of the interaction among growing seasons, locations and cultivars for late blight was observed in terms of r-value.

The resistance to late blight may be affected by environmental conditions (Umaerus and Umaerus, 1994 and Deadman 2006). Genotype $\times$ Environment interaction can be studied temporally (two or more seasons testing at a location) or spatially (several locations) or a combination of these (Cotes et al., 2002). In this work, we studied the interaction between $10 \mathrm{G} \times \mathrm{E}$ and we found that the variation in adult plant response to late blight infection between PR of potato cultivars and susceptible ones, was consistently attributed to their genetic structure rather than the changes in environmental conditions over two years.

With the emergence of new genotypes of the fungus like $P$. infestans and with the potential for genetic recombination between A1 and A2 mating types, information on the effect of pathogen $\mathrm{x}$ host $\mathrm{x}$ environment interactions on the phenotypic expression of stability of resistance to late blight in potatoes will become extremely important (Haynes et al., 1998). Information regarding the mating types of $P$. infestans in the three locations studied was not elucidated in our study before we started this research. However, El-Korany (1994) and El-Sheikh et al. (2005) reported that mating types A1 and A2 are present in Egypt and their dominance over years and locations varied. Also, El-Ganainy (2013) through an intensive survey stated that A1, A2 and self-fertile of the fungus like P. infestans were dominant over 3 years of study in Gharbia and Beheira governorates. While, in Kafr El-Sheikh, only mating types A1 and A2 were frequently isolated. The previous findings indicating that the ten cultivars evaluated in this study were under pressure of the three mating types of $P$. infestans in different environmental conditions.

The present study is one of few studies that deal with this kind of multi-location trials on potato varieties in Egypt. Nevertheless, information on the phenotypic stability of potato is not elucidated in our work. But, the ability to grow well in different environments does not exist in all potato genotypes (Tai and Young 1989).

\section{Conclusion}

In the current study, three potato cultivars, i.e., Burren, Cara and Bellini exhibited the highest levels of PR to late blight under field conditions. Cv. Bellini

Egypt. J. Phytopathol., Vol. 46, No. 2 (2018) 
was the most stable in terms PR to late blight under a wide range of environmental conditions. The evaluation of the behavior of given genotypes under specific and changeable conditions of the environment provides valuable information on several aspects: how the cultivar responds to changeable conditions, how adaptable it is under a wide set of environments (locations and seasons) and what is the area of its eventual distribution. The stability analysis can also help the breeder to monitor the level of resistance to the tested plant materials as well as to monitor the disease pressure in different environments.

\section{Ref e r e n c es}

Arafa, R.A.; Soliman, N.E.K.; Moussa, O.M.; Kamel, S.M. and Shirasawa, K. 2017. Characterization of Egyptian Phytophthora infestans population using simple sequence repeat markers. J. of General Plant Pathol., 84: 104-107.

Andrivon, D. 1995. Biology, ecology, and epidemiology of the potato late blight pathogen Phytophthora infestans in soil. Phytopathology, 85: 1053-1056.

Chen, A.L.; Liu, C.Y.; Chen, C.H.; Wang, J.F.; Liao, Y.C.; Chang, C.H.; Tsai, M.H.; Hwu, K.K. and Chen K.Y. 2014. Reassessment of QTLs for late blight resistance in the tomato accession L3708 using a Restriction Site Associated DNA (RAD) linkage map and highly aggressive isolates of Phytophthorainfestans. PLoS ONE, 9(5): e96417.

Colon, L.T. and Budding, D.J. 1988. Resistance to late blight (Phytophthora infestans) in ten wild Solanum species. Euphytica, 39(3): 77-86.

Colon, L.T.; Jansen, R.C. and Budding, D.J. 1995. Partial resistance to late blight (Phytophthora infestans) in hybrid progenies of four South American Solanum species crossed with diploid S. tuberosum. Theor. and App.Gen., 90: 691-698.

Cotes, J.M., Nustez, C.E., Martinez, R., and Estrada, N. 2002. Analyzing genotype by environment interaction in potato using yield-stability index. Am. J. of Potato Res., 79(3): 211-218.

Deadman, M.L. 2006. Epidemiological consequences of plant disease resistance. In: Cooke, B.M.; Jones, G.D. and Kaye, B.; 2nd Edition. The Epidemiology of Plant Diseases. Netherlands. Springer, 139-157.

Eberhart, S.T. and Russell, W.A. 1966. Stability parameters for comparing varieties. Crop Sci., 6(1): 36-40.

El-Ganiany, S.M.A. 2013. Epidemiology and characterization of Phytophthora infestans, the causal agent of late blight disease in potato. Ph.D., Thesis Fac. of Agric. Minufiya Univ., 180 pp.

El-Korany, A.E. 1994. Pathological studies on late blight of potato caused by 
Phytophthora infestans. Ismalia, Egypt. Dissertation, Fac. of Agric. Suez Canal Univ., 165pp.

El-Sheikh, M.A.; El-Farnawany, M.A. and El-Korany, A.E. 2005. Characteristics of the Egyptian population of tomato isolates of Phytophthora infestans. J. Agric. Env. Sci., Alex. Univ., 4(1): 37-55.

Gopal, J. and Singh, B.P. 2003. Screening potatoes for resistance to late blight (Phytophthora infestans) under field conditions. Potato Res., 46(1-2): 47-56.

Haverkort, A.J.; Struik, P.; Visser, R.G.F. and Jacobsen, E. 2009. Applied biotechnology to combat late blight in potato caused by Phytophthora infestans. Potato Res., 52:249-264.

Haverkort, A.J.; Boonekamp, P.M.; Hutten, R.; Jacobsen, E. and Lotz, L.A.P. 2008. Societal costs of late blight in potato and prospects of durable resistance through cisgenic modification. Potato Res., 51:47-57.

Haynes, K.G.; Lamber,t D.H.; Christ, B.J.; Weingartner, D.P.; Douches, D.S.; Backlund, J.E.; Secor, G.; Fry, W.E. and Stevenson, W. 1998. Phenotypic stability of resistance to late blight in potato clones evaluated at eight sites in the United States. Am .J. Potato Res., 75: 211-217.

Haynes, K.G. and Weingartner, D.P. 2004. The use of area under the disease progress curve to assess resistance to late blight in potato germplasm. Am. J. Potato Res., 81(2): 137-141.

Jenkins, J.C. and Jones, R.K. 2003. Classifying the relative host reaction in potato cultivars and breeding lines to the US-8 strain of Phytophthora infestans in Minnesota. Plant Dis., 87(8): 983-990.

Johnson, D.A.; Alldredge, J.R. and Hamm, P.B. 1998. Expansion of potato late blight forecasting models for the Colombian Basin of Washington and Oregon. Plant Dis., 82(6): 642-645.

Kathleen, G.H. and Peter, W. 2004. The use of area under the disease progress Curve to Assess Resistance to Late Blight in Potato Germplasm. Am. J. Potato Res., 81:137-141.

Kirk, W.W.; Abu-El-Samen, F.M.; Muhinyuza, J.B.; Hammerschmidt, R.; Douches, D.S.; Thillc, C.A.; Groza, H. and Thompson, A. 2005. Evaluation of potato late blight management utilizing host plant resistance and reduced rates and frequencies of fungicide applications. Crop Protec., 24: 961-970.

Pandey, H.N.; Menon, T.C.M. and Rao, M.V. 1989. A simple formula for calculating area under disease progress curve. Rachis, 8(2): 38-39.

Egypt. J. Phytopathol., Vol. 46, No. 2 (2018) 
Parlevliet, J.E. 1979. Components of resistance that reduce the rate of epidemic development. Ann. Rev. Phytopathol., 17: 203-222.

Rivera-Peña, A. 1990. Wild tuber-bearing species of Solanum and incidence of Phytophthora infestans (Mont.) de Bary on the western slopes of the volcano Nevado de Toluca. 5. Type of resistance to P. infestans. Potato Res., 33:479-486.

Snedecor, G.W. and, Cochran, W.G. 1980. Statistical Methods. 7th ed. Iowa State Univ. Press, Iowa, USA.

Sparks, A.H.; Forbes. G.A.; Hijmans, R.J. and Garrett, K.A. 2014. Climate change may have limited effect on global risk of potato late blight. Global Change Biol., 20(12): 3621-3631.

Tai, G.C.C. and Young, D.A. 1989. Performance and prediction of potato genotypes tested in international trials. Euphytica, 42: 275-84.

Tooley, P.W. 1990. Variation in resistance to Phytophthora infestans among 21 Solanum verrucosum plant introductions. Amer. Potato J., 67: 491-498.

Umaerus, V. and Umaerus, M. 1994. Inheritance of resistance to late blight. UK. CAB International. Bradshaw, J.E. and Machay, G. R., Potato Genet, 365-402.

Van der Plank, J.E. 1963. Plant Disease: Epidemics and Control. Academic Press, New York, 35-71.

Workman, D. 2018. Trade Map, International Trade Centre. Accessed on May 24, 2018. http://www.worldstopexports.com/potatoes-exports-by-country.

Wricke, G. 1962. Via a method for recording the ecological spread in field trials. Z.F. Pflanzenzuechi, 47:92-96.

(Received 30/08/2018; in revised form 24/09/2018) 


\section{ثبات المقاومة الجزيئية فى بعض أصناف البطاطس البط البها

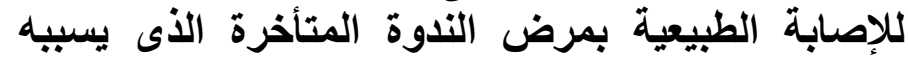 Phytophthora infestans طارق عبد المنعم عيسى ، سعيد محما حسن كامل ، أحمد محمود

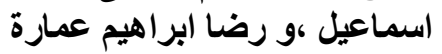 \\ معهل بحوث أمراض النباتات ، مركز البحوث الزراعية ، الجيزة ، مصر إنر}

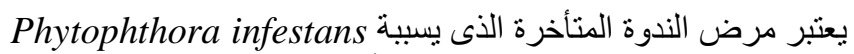

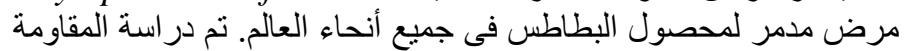
الجزئية ل Phytophthora infestans فى أصناف البطاطس المختلفة

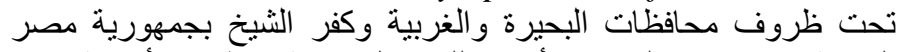

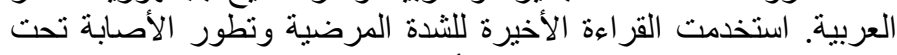

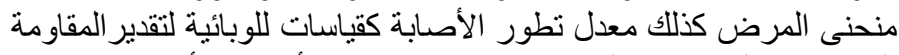

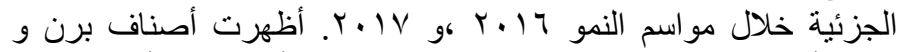

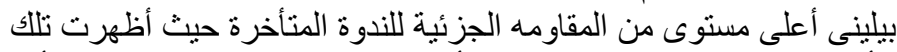

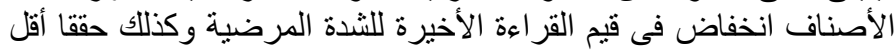

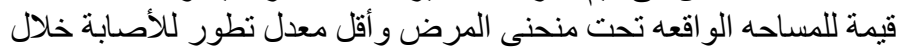

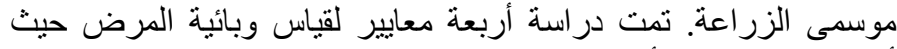

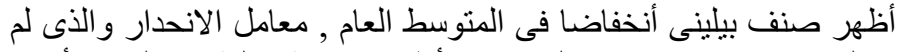

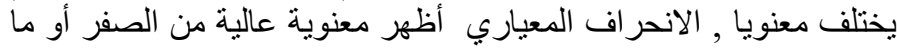

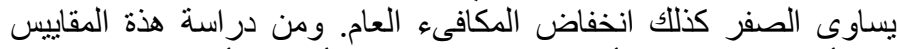

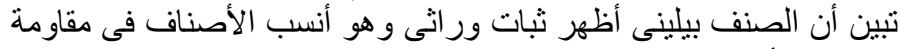

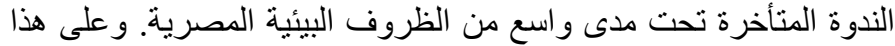

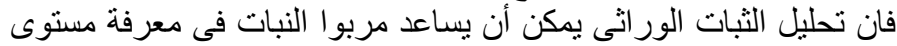
المقاومة فى النباتات المختبرة كذللك التأثير ات العاتئ التية للمسبيات المرضية تحت الظروف البيئية المختلفة. 